\title{
Strategy Development of Commodity Potato Granola (Solanum Tuberosom $L$ ) in Tombolopao District Gowa Regency
}

\author{
Muh Ikmal Saleh¹, Didi Rukmana², Nurdjanah Hamid³, Siti Bulkis², Mahyuddin², Sitti Nurani \\ Sirajuddin ${ }^{2}$
}

${ }^{1}$ Agribusiness Study Program Students, Postgraduate School of Hasanuddin University, Indonesia

${ }^{2}$ Lecturer of Agribusiness Program, Postgraduate School of Hasanuddin University, Indonesia

${ }^{3}$ Lecturer of Managemen Department of Hasanuddin University, Indonesia

Correspondence Author: Muh Ikmal Saleh, Agribusiness Study Program Students, Postgraduate School of Hasanuddin University Email: muhikma10102@gmail.com

Received date: 28 August 2019, Accepted date: 2 December 2019, Online date: 25 December 2019

Copyright: (C) 2019 Muh Ikmal Saleh et al., This is an open-access article distributed under the terms of the Creative Commons Attribution License, which permits unrestricted use, distribution, and reproduction in any medium, provided the original author and source are credited.

\begin{abstract}
This study aimed to describe the granola potato agribusiness in Tombolopao District, identify the strategic issue of granola potato agribusiness to see internal and external and external conditions as well as formulate priority strategies in formulating strategies for developing granola potato agribusiness in Tombolopao District, Gowa Regency. The method used in this research is descriptive analysis, farm analysis, IFE and EFE analysis. The results of the analysis show that the condition of the potato agribusiness system in Tombolopao District is still not running optimally, due to the non-functioning of the upstream subsystem, where the actors in the procurement of production facilities are still carried out individually which causes the lack of production inputs, namely the problem of granola potato seeds. In the farming subsystem, potato cultivation has provided benefits to farmers, this farming is feasible to be developed with $\mathbf{r} / \mathbf{c}$ for a cash cost of 3.30 , which means that everyone rupiah cash costs incurred will provide revenue of 3.30, while $r$ / c for the cost a total of 3.25, which means that everyone rupiah cash costs incurred will provide as much as 3.25 receipts. In the marketing subsystem, potatoes have been marketed to Kalimantan and Southeast Sulawesi. Prices are determined by collectors. In the downstream (processing) subsystem, not all of the processed potato entrepreneurs use potatoes as their raw material, which causes new potatoes to be sold in fresh products. In the service and support subsystems, supported by agricultural extension workers who accompany and provide information related to potato cultivation, but from supporting capital, farmers have not utilized credit provided by financial institutions because they still use private capital.

Based on the identification of key internal factors, high demand with a weight of 3.60 is the main strength and weaknesses are at the level of capital which is still limited with a weight of 2.00 while the external key factor of the opportunity factor that ranks first is the support of the government with a score of 0.22 and weaknesses in the location of relatively expensive production facilities with a score of 0.18 .
\end{abstract}

Keywords: Agribusiness, Strategy development, Granola Potatoes.

\section{INTRODUCTION}

Potatoes are a horticultural commodity that has development opportunities in agribusiness and agribusiness. The magnitude of this opportunity is due to relatively stable potato prices, high commercial potential, commercial segments that can be selected according to capital, guaranteed and safe markets. Also, potatoes have a longer shelf life than other vegetables such as onions, cabbage, and beans. Development of global institutions that support potato agribusiness services through institutional farmers and stakeholders. One of the global agribusiness support services for farmers is the National Potato Council (NPC), which is a voluntary association of potato producers that focuses on government policies and regulations at the national and international levels. The NPC acts as a channel for the aspirations of the potato industry in Washington DC and works to improve conditions that allow farmers to produce, The development strategy for agriculture is to compensate for the degradation of agricultural land and the dimensions of society to control changes in the function of agricultural labor[1] transport and market their products in the United States and throughout the world. Indonesia is an agricultural country that has a fairly wide range of agriculture. Seeing this extraordinary benefit, potatoes have the potential to generate foreign exchange through exports. It must also be supported by a good agribusiness system to produce quality products. The agribusiness system is the system that contributes the most to the formation of gross domestic product (GDP), employment opportunities and opportunities to participate in increasing exports [2]. The diversity of agribusiness systems is the totality or performance units consisting of upstream subsystems, agriculture, performance processing, marketing, institutions and supporting institutions. 
Table 1: Harvested area, production and productivity of potatoes in Indonesia in 2014-2018

\begin{tabular}{|c|c|c|c|}
\hline Year & Harvested Area (Ha) & Production (Tons) & Produktivity (Tons/Ha) \\
\hline 2014 & 76.291 & 1.347 .815 & 17.67 \\
\hline 2015 & 66.983 & 12.192 .697 & 182.03 \\
\hline 2016 & 6.645 & 12.130 .384 & 1825.49 \\
\hline 2017 & 75.611 & 11.647 .381 & 154.04 \\
\hline 2018 & 68.683 & 12.847 .597 & 187.06 \\
\hline Average & 58.842 .6 & 10.033 .175 & 473.26 \\
\hline
\end{tabular}

Source: Ministry of Agriculture (Directorate General of Horticulture) 2019

Table 1 shows that the area harvested, the production and productivity of potatoes in Indonesia from 2014 to 2018 fluctuated the area of production, production and productivity, but even so, the decrease was relatively insignificant. The potato plant is a type of tuber-shaped plant native to Europe. Potato plants are suitable in subtropical climates such as Indonesia, one of which is located in the province of South Sulawesi. Potato plants can have a positive impact on farmers, according to data [2]is as follows:

Table 2: Harvested area, production and productivity of potatoes in South Sulawesi

\begin{tabular}{|c|c|c|c|}
\hline Year & Harvested Area (Ha) & Production (Tons) & Produktivity (Tons/Ha) \\
\hline 2012 & 1433 & 118802 & 82.90 \\
\hline 2013 & 1654 & 18420 & 11.14 \\
\hline 2014 & 1816 & 23444 & 12.91 \\
\hline 2015 & 1342 & 2627 & 1.96 \\
\hline 2016 & 1925 & 295215 & 153.36 \\
\hline Average & 1634 & 91701.6 & 52.45 \\
\hline
\end{tabular}

Source: BPS South Sulawesi Province 2019

Table 2 above shows that the crop area that can affect potato production, the larger the production area, the greater the production and productivity The social aspect in the form of government inconsistency in protecting farmers, is by forcing farmers to find work to increase selling prices [3]

The subdistrict of Tombolopao Gowa is one of the subdistricts of the province of South Sulawesi, which is one of the three districts in the potato production center. Year after year in the Gowa Regency The level of community participation at the rehabilitation stage of degraded land is related to the area of land, age and education that are incorporated in internal and external conditions to increase community participation. [4] area there are 18 districts that have 32,174 hectares of rice paddies, drylands with an area of 10,320 hectares, each of which has reliable products that can be seen in the following table:

Gowa Regency has climatic types C and D (Smith Ferguson) with an average rainfall of 2000-3000 mm/year that has a different air humidity between the highlands and lowlands, has 4 types of soil, namely alluvial in the lowlands, mountainous regions Latosol Pada, Andosol In the mountainous regions, red and yellow Podsolik in the census area and the population in Gowa Regency in 2018 totaled 751,981 people with 370,151 men and 381,830 people [5].

Table 3: Potato production based on the area of harvest, production and productivity in the Gowa regency

\begin{tabular}{|c|c|c|c|}
\hline Year & Harvested Area (Ha) & Production (Tons) & Productivity (Tons/Ha) \\
\hline 2014 & 855 & 145350 & 170 \\
\hline 2015 & 799 & 13583 & 17 \\
\hline 2016 & 2002 & 346196 & 173 \\
\hline 2017 & 2002 & 346196 & 173 \\
\hline 2018 & 2158 & 376012 & 174 \\
\hline Average & 1563.2 & 245467.4 & 141 \\
\hline
\end{tabular}

Source: Department of Food and Horticulture, Gowa Regency 2019

The table above shows that the harvested area, production, and productivity of potato plants in the Gowa Regency have increased from 2014 to 2018.

Tombolopao District is a district that is located very close to consumers or markets, only around $70 \mathrm{~km}$ from the center of Makassar. The number of villages/village offices is 9 villages/village offices which are the result of the division from the Tinggimoncong district. The total area of Tombolopao district is $251.82 \mathrm{~km}^{2}$ with a population of 14,955 men, 14,508 women with a total of 29,463 . This is a benchmark that the distance of farmers to see a very large market potential so that they can obtain a sale value from high production and obtain superior seeds, one of which is the production of granola potatoes which are in the district of Tombolopao. The following is the level of harvested area, production and productivity of potatoes in the Tombolopao district: 
Table 4: Potato Production by Harvest Area, Production, and Productivity in Tombolopao District

\begin{tabular}{|c|c|c|c|}
\hline Year & Harvested Area (Ha) & Production (Tons) & Productivity (Tons/Ha) \\
\hline 2014 & 362 & 57540 & 158.95 \\
\hline 2015 & 536 & 9630 & 17.97 \\
\hline 2016 & 554 & 89580 & 161.70 \\
\hline 2017 & 712 & 128160 & 180.00 \\
\hline 2018 & 555 & 95870 & 172.74 \\
\hline Average & 543.8 & 76156 & 138 \\
\hline
\end{tabular}

Source: Department of Food and Horticulture, Gowa Regency 2019

Table 4 based on the level of production, harvested area and productivity of potatoes in the Tombolopao district fluctuated greatly from 2014 to 2018 because of the lack of knowledge for farmers to use superior seeds and lack of capital to obtain these superior seeds for most farmers so the farmers planted the seeds repeatedly which resulted in decreased productivity.

One type of potato that is cultivated by people in the District of Tombolopao is granola potato. Potatoes granola contains more carbohydrates and lower water content. This makes processed granola potatoes into chips and other foods will be more tasty and delicious. In terms of cultivation, potato granola becomes more resistant to pests or diseases. Potato granola is an vital vegetable commodity that has prospective business opportunities. Until whenever this product will still be consumed and is needed by the community. This is because in granola potatoes there are some sodium contents, as a source of vitamins C and B1, mineral phosphorus, iron and potassium.

One way to develop a business is to cycle the market share by increasing networks to various regions so that it needs to improve communication with relevant institutions and form and develop nursery businesses (Sirajuddin dkk, 2011) [6].

\section{RESEARCH METHODS}

This research was conducted in the District of Tombolopao, Gowa Regency. This research was conducted by purposive sampling with the location requirements as the development of potato commodities. This research was carried out from July until September 2019.

Determination of the number of farmers is done by selecting respondents as many as 30 farmers who were selected using probability sampling techniques, namely simple random sampling where respondents are taken from all members of the granola potato farmer population that is done randomly without regard to strata in the population [7].

To determine the strategy for developing potato agribusiness in the Tombolopao district of Gowa district, the speakers were taken from stakeholders and related experts/experts who have the ability to provide an assessment of factors that greatly affect the development of the granola potato commodity in the Tombolopao District, namely:

1. Head of Horticulture, Gowa Regency.

2. Head of the field of processing and Marketing of Agricultural Production Products of the Gowa Regency Agriculture Office.

3. Agricultural Extension Workers

4. Head of Mamampang Village

5. Head of Kanreapia Village

The proportion of each stakeholder varies according to the level of interest of stakeholders and decision-makers in the development of granola potato agribusiness. Of the five informants will be divided into three levels with the reason, the higher the level, the informant is the most expert in strategic decision making, namely:

1. the first informant is the first level with a proportion of 36 percent, this is done because the voting proportion must be below 50 percent as evidence that it is not only the resource person who determines future decisions,

2. The second, third and fourth information is the second level with a proportion of 17 percent which is half of the proportion of the first level and,

3. The fifth informant is the third level with a proportion of 8 percent which is half of the proportion of the second level.

The data obtained are primary and secondary data which are processed by quantitative and qualitative methods. In this research, the analysis that will be used is descriptive analysis, farming analysis, IFE, and EFE analysis.

In this research, there are two parties, namely external and internal parties. Internal parties in this study are the actors in the on farm subsystem, namely potato farmers. On the other hand, the external parties in this study were divided into two, namely external tasks and external remote. The external task force consists of (1) upstream subsystem actors, namely the nursery industry and providers of production facilities; (2) marketing subsystem actors, namely suppliers (traders) and potato consumers; (3) downstream (processing) subsystem actors, namely the potato processing industry; and (4) subsystem of supporting institutions, namely financial institutions. While the external remote is the local government at the research location.

\section{RESULTS AND DISCUSSION}

\section{Description of Potato Agribusiness in Tombolopao District, Gowa District}




\section{Upstream Subsystem}

Granola potato agribusiness included in the upstream subsystem is the provision of seeds which is a benchmark of success in the cultivation of potato granola characterized by the availability of quality seeds where the parent, not defective and breeding is done correctly because it has the linkages of various elements so that the cultivation of potatoes The granola reaches the desired target [6]

Granola potato agribusiness in the Tombolopao district area shows that the business carried out by farmers for breeding business has not fully used technology as a whole, which is only a nursery done by farmers only to meet the needs for sustainable production. The problems faced by granola potato farmers in the District of Tombolopao Gowa Regency are as follows:

a. The lack of granola seedlings is used to supply farmers' needs.

b. Lack of human resources to utilize existing technology.

c. Uncertain season

d. Seeds that are affected by the disease range because of the lack of supply of certified seed

e. There is no training provided by the government in nursery techniques and cooperation between the government and farmers to deal with the scarcity of quality seeds.

f. Lack of analysis or knowledge to get around the market.

\section{Farm Subsystem}

Farming costs are all costs incurred by farmers when doing granola potato farming. Based on the cultivation technique of potato granola farming, the cost of this farm consists of costs that are completed and costs are shortened 9 [8]

Costs paid include the cost of seeds, pesticide costs, and the cost of purchasing manure, artificial fertilizer, the cost of Foreign Family Labor (TKLK) and the Land and Building Tax (PBB).

The average number of seeds used by farmers is $1,143 \mathrm{~kg} / \mathrm{ha}$. The average cost of seedlings per hectare incurred by granola potato farmers is IDR. 8,735,294, - /ha. The price of granola potato seeds at the time of the study was IDR. $15,000 / \mathrm{kg}$.

In fertilizing activities, the types of fertilizer commonly used by respondents for the cultivation of potato granola are quite diverse. Not only from the type of fertilizer but also from the dose used. The types of fertilizer commonly used are manure, urea and ZA. Where the costs to be paid by respondents for the purchase of fertilizer are manure for IDR. 12,000 / sack, urea fertilizer for IDR. 110,000 / sack, ZA fertilizer for IDR. 100,000, - / sack.

The amount of fertilizer used by farmers depends on the area of land they have and the cost they spend depends on the amount of fertilizer used. This is as presented in the Appendix. The following table presents the average fertilizer use and costs incurred by the respondent farmers in the granola potato farming.

Table 5: Average per hectare of fertilizer use and fertilizer purchase costs

\begin{tabular}{|c|c|c|}
\hline Types of Fertilizers & Average usage / sack & Cost \\
\hline Manure & 153.33 & 1.840 .000 \\
ZA & 1.14 & 114.379 \\
Urea fertilize & 2.48 & 273.202 \\
\hline Total & 156.96 & 2.227 .581 \\
\hline
\end{tabular}

Source. Primary data after processing, 2019

In the table above you can see that the total cost of buying fertilizers per hectare is IDR 2,227,581. This rate is obtained based on the amount of fertilizer used by the respondent's farmers. To maintain good productivity of granola potatoes, respondents not only carry out fertilization activities but also carry out pest and disease control activities by spraying pesticides. The amount of pesticide used by farmers depends on the area of land they have and the cost they spend depends on the amount of pesticide used. In the cultivation of potato granola, farmers only use pesticides according to their needs, this is because potato granola plants are resistant to diseases. Income that provides financial benefits to farmers by collaborating with the government with indicators of the ratio model, personal prices [9]

From the results of the study, it was discovered that the method of pest control by farmers is to cut and discard the unproductive petiole so that sunlight and sprayed pesticides can enter the productive leaves. The average use of pesticides used by farmers per hectare is 2 bottles and the average cost incurred per hectare is IDR 58,000. Costs incurred for the purchase of pesticides amounted to IDR 29,000 / $100 \mathrm{ml}$ bottle as necessary.

Income is the value received by farmers from the sale of their farms. The income here can be divided into two, namely cash receipts and calculated income. Cash receipts are obtained from the number of products sold multiplied by the sale price of the farmer. While the estimated income is obtained from the amount of production and it will be used as a seed multiplied by the sale price of the farmer and to see the difference in income and producers of potato granola. The average production per hectare of granola potatoes is IDR $7,326.80 \mathrm{~kg}$. The sale price of potato granola is IDR 7,254.90/ $\mathrm{Kg}$. Thus, the average income of the farmer per hectare is IDR 55,732,026.14 and the estimated average income is IDR. 29,141,667 / ha.

The income of agricultural cash costs is the difference between cash receipts and fees paid. The average income of granola potato farmers per hectare is IDR $38,821,601.31$ ha.

The total cost of agriculture income is the difference between total revenue and total costs. The average income for the total cost (benefit) of potato granola producers per hectare is IDR 58,744,304.58/ha. For more details, data on the amount of income, 
income and average earnings of granola potato farmers in the district of Tombolopao, Gowa Regency can be seen in the following table6

Table 6: Average per hectare of income and income, producers of potato granola in the District of Tombolopao

\begin{tabular}{|c|l|c|}
\hline Number & \multicolumn{1}{|c|}{ Explanation } & Total (IDR) \\
\hline 1. & Cash receipt & 55.732 .026 .14 \\
2. & Calculated receipt & 29.141 .667 \\
3. & Total penerimaan & 84.873 .692 .81 \\
& Total receipt & \\
& $\checkmark \quad$ TKLK & 1.078 .431 .37 \\
& $\checkmark \quad$ Seedlings & 8.735 .294 .12 \\
& $\checkmark \quad$ Fertilizer & 2.227 .581 .699 \\
& $\checkmark \quad$ Pesticides & 4.822 .385 .62 \\
5. & $\checkmark \quad$ PBB & 46.732 .03 \\
& Total fees paid & 16.910 .424 .84 \\
& Cost calculated & \\
& $\checkmark \quad$ TKDK & 356.862 .75 \\
& $\checkmark \quad$ Seedlings & 8.735 .294 .12 \\
6. & $\checkmark$ Depreciation of Equipment & 126.806 .54 \\
7. & Total costs calculated & 9.218 .963 .40 \\
8. & Total cost & 26.129 .388 .24 \\
9. & Rash income & 38.821 .601 .31 \\
10. & Revenue from total costs & 58.744 .304 .58 \\
\hline
\end{tabular}

Source. Primary data after processing, 2019

In the table above it can be seen that the $\mathrm{R} / \mathrm{C}$ for the 3.30 cash fee means that each rupee of the cash costs incurred will provide an income of 3.30, while the R / C for the total cost is 3.25 which means that for each rupee the fee cash issued will provide receipts of 3.25. Because the $\mathrm{R} / \mathrm{C}$ ratio produced in potato granola farming is greater than one, it is feasible to develop this agriculture.

\section{Downstream Subsystem}

From field observations found in Tombolopao District, Gowa Regency, the granola potato business in the downstream subsystem has not been fully processed into a product that can increase economic value. However, no one was involved in the processing sector in the study area, which resulted in the post-harvest farmers only moving the plants from the garden to the farmer's garden to condense and sort the potatoes they will sell

\section{Marketing Subsystem}

The main problems faced by this subsystem are limited capital problems and the commercialization of fresh products to be sold because farmers have limited access to market information, especially in relation to demand and pricing. This is due to a large number of parties involved in the marketing process where traders meet higher than large traders, but some granola papa producers who have direct access to large traders get higher profits and vice versa to make it more feasible. To say that the monopsony market is a market dominated by buyers, which determines the price and quality that fluctuates a lot. As for the standard and quality which are reasonable prices, so that the mutual benefits between the two parties, namely producers and consumers can be seen in the problem description, it can be seen in the downstream Granola potato subsystem:

a. Farmers are in a weak position to determine prices.

b. Farmers sell their products in fresh form

c. Farmers do not know or are not up to date about the product requirements demanded by the market

d. Farmers do not fully know the quality or reasonable price.

From the results of the research, it can be found that several commercial channels through which granola potatoes are switched from farmers to collectors to large traders, to retailers to consumers, where prices apply at each of their different levels and prices at farmers are the lowest and distribution of granola potatoes has been commercialized in several areas around the Tombolopao District and already in the Kalimantan and Southeast Sulawesi regions, but the price difference is very drastically determined by collectors and / or intermediaries can be dangerous for farmers.

\section{Institutional and Support Subsystems}

The current government policy regarding granola potatoes is still related to general crop cultivation, not specifically made. Policies related to granola potatoes must be supported by all parties, not only the Ministry of Agriculture, but also other parties, such as the Ministry of Cooperatives (related to cooperative policies), the Ministry of Economy related to business and credit, 
including banks, the Ministry of Trade and local governments that produce granola potatoes. Some of the problems associated with the red potato agribusiness support subsystem are as follows:

a. Existing agricultural institutions are still very weak administratively because there is no legal legality

b. The capacity of extension agents as technology sources and intermediary objectives in technology transfer has not been increased.

c. Institutional support for research in the development of granola potato agribusiness is still lacking

d. Institutional support for information technology does not yet exist in various forms of media.

e. Bank institutional capital to improve the performance of potato cultivation is not yet available

f. Government institutional support in preparation and facilitation of infrastructure for farmers, producers, collectors and traders.

\section{IFE and EFE Matrix}

The key to success (key success factor) is the IFE (Internal Factor Evaluation) matrix for internal factors and the EFE (External Factor Evaluation) matrix for external factors. The IFE matrix summarizes and evaluates key internal factors in the form of major strengths and weaknesses in various functional areas in a business. This matrix can be used as a basis for identifying and evaluating relationships between these fields. The EFE matrix allows the strategic planner to summarize and evaluate the company's key external factors [8]

\section{a. IFE Matrix}

The IFE matrix is obtained through respondents' evaluation of the extent to which internal strategic factors affect the agribusiness of granola potatoes. Respondents assessed the weight and ranking of each internal strategic factor. In the following table, the IFE matrix of potato granola agribusiness in Tombolopao district, Gowa Regency.

Based on the analysis shown in the IFE matrix table that has been done produces a weighted value of 2.88 , meaning that the Tombolopao district is able to utilize the strengths and minimize weaknesses in the development of granola potato agribusiness. The total value can identify that the ability of granola potato agribusiness in the research location in responding to its internal environment is still average.

Analysis of internal key factors on strengths was chosen with the highest score and on the weaknesses, factors were chosen with the lowest score. The main strengths in the analysis of the internal environment of potato granola agribusiness are a high sense of kinship with the highest score of 0.47 and the main weakness is the payment system that is unfavorable to farmers with the lowest score of 0.24 .

Table 7: IFE Matrix of granola potato agribusiness in Tombolopao district, Gowa Regency

\begin{tabular}{|c|c|c|c|}
\hline \multicolumn{4}{|c|}{ Internal Key Factors } \\
\hline \multirow{2}{*}{ Opportunity } & Average & Average & Score \\
\hline & Weight (a) & Rating (b) & (a) $\times($ (b) \\
\hline Availability of Certified Seeds & 0.16 & 3.00 & 0.47 \\
\hline Weather and climate soil conditions & 0.13 & 3.00 & 0.39 \\
\hline Location close to the market & 0.12 & 2.80 & 0.34 \\
\hline High demand & 0.12 & 3.60 & 0.44 \\
\hline Experience in farming & 0.12 & 3.00 & 0.35 \\
\hline \multicolumn{4}{|l|}{ Weakness } \\
\hline Capital is still limited & 0.12 & 2.00 & 0.24 \\
\hline The price is set by the trader & 0.12 & 2.80 & 0.32 \\
\hline Marketing is still limited & 0.12 & 2.80 & 0.33 \\
\hline Total & \multicolumn{2}{|c|}{1.00} & 2.88 \\
\hline
\end{tabular}

Source. Primary data after processing, 2019

\section{b. EFE Matrix}

The EFE matrix is obtained through respondents' assessments of external strategic factors affecting the company. Each respondent gives an assessment of the weights and ratings of each company's external strategic factors as follows:

Table 8: EFE matrix of granola potato agribusiness in Tombolopao District, Gowa Regency

\begin{tabular}{|c|c|c|c|}
\hline \multicolumn{3}{|c|}{ External Key Factors } \\
\hline \multirow{2}{*}{ Opportunity } & Average & Average & Score \\
\cline { 2 - 4 } & Weight (a) & Rating (b) & (a) $\mathbf{x}(\mathbf{b})$ \\
\hline Government Support & 0.22 & 0.34 & 1.03 \\
\hline Very high market demand & 0.19 & 0.29 & 0.87 \\
\hline Technology advances & 0.18 & 0.26 & 0.72 \\
\hline Regional trade & 0.18 & 0.31 & 1.12 \\
\hline Threat & & & \\
\hline
\end{tabular}




\begin{tabular}{|c|c|c|c|}
\hline High pest attack & 0.18 & 0.18 & 0.00 \\
\hline The price of production facilities is relatively expensive & 0.18 & 0.21 & 0.42 \\
\hline Total & \multicolumn{2}{|c|}{1.00} & 4.15 \\
\hline
\end{tabular}

Source. Primary data after processing, 2019

Based on the table above shows that the EFE matrix analysis carried out yielded a weighted value of 4.15, meaning that in the District Tombolopao Gowa district was able to take advantage of opportunities to avoid threats in the development of granola potato agribusiness. Analysis of the external key factors on the opportunity chosen with the highest score and on the threat factor chosen with the lowest score. The opportunity factor shows the main opportunity in the external environment analysis of granola potato agribusiness with the highest weighted value, namely the support of the government with a score of 1.03 with an average weight of 0.22 and. The highest score on the opportunity factor of 0.44 becomes a benchmark that the research location responds to both the support in the form of assistance and activities. While the threat factor indicates the main threat with the highest score on the threat factor of 0.42 shows that when there are political shocks such as riots in the elections and local elections causing the closure of several local markets so that the availability of Granola potatoes on the market decreases resulting in the price of granola potatoes has increased. However, the price at the farm level is low due to the accumulation of farmers' yields.

\section{CONCLUSION}

From the results of the discussion, it can be concluded that:

1. The condition of the granola potato agribusiness system in the district of Tombolopao, Gowa regency is still not running as a whole, which is caused by not functioning optimally upstream subitem, marketing subitem, downstream subsystem, service and support subitem and farming subsystem

2. Based on internal and external factors, the relationship between the desire of farmers to always go forward must be accompanied by support from the government.

\section{REFERENCES}

[1] R Marsuki Iswandi. 2016. Institutional Strategies in Sustainable Agricultural Development at Mining Rim Area. Research Journal Of Fisheries And Hydrobiology 11(6), June, Pages: 12-17

[2] Departemen Pertanian. 2012. Konsumsi rata-rata per kapita per minggu beberapa bahan 2007-20011 [internet]

[3] [BPS] Badan Pusat Statistik 2019.Statistik Sulawesi - Selatan 2019. Sulsel (ID). BPS Prov. SulSel

[4] Dewa Oka et . al. 2016 Community Participation on Evaluation Stage in Critical Land Rehabilitation Program. Advance in Environmental Biology.

[5] [BPS] Badan Pusat Statistik 2019.Statistik Kabupaten Gowa 2019. Gowa (ID).BPS Kab. Gowa

[6] Harmina et. al, 2016,. Socio-economic meanings of agricultural land conversion for airport area development of farmers. Advance in Environmental Biology.

[7] Sirajuddin et. Al., 2011. Strategi Pengembangan Ternak Kelinci di Kabupaten Soppeng

[8] Arikunto, S. 2010.Prosedur Penelitian Suatu Pendekatan Praktik. Jakarta:Rineka Cipta.

[9] Sitti Nurani Sirajuddin et al. 2016. Competitiveness of Beef Cattle Fattening in Kulo. Subdistrict, Sidrap District South Sulawesi, Advances in Environmental Biology, 10(1), 171-175

[10] Hastuti EY. 2008. Pengaruh penerapan sistem agribisnis terhadap peningkatan pendapatan petani sayuran di Kabupaten Boyolali [tesis]. Semarang (ID): Universitas Dipenogoro8

[11] Suratyah K. 2006. Ilmu Usahatani. Jakarta (ID). Penebar Swadaya.

[12] David FR. 2009 Manajemen Strategi Sulistio P dan Mahardika H, Penerjemah; Rahoyo S, editor; Edisi dua belas. Jakarta (ID): Salemba Empat. Terjemahan dari: Strategic Management ${ }^{3}$ Concepts and Cases, 10 th ed. 